\title{
REPRODUCTIVE BIOLOGY OF SABINE'S GULL IN THE CANADIAN ARCTIC
}

\author{
Author(s): Iain J. Stenhouse, H. Grant Gilchrist, William A. Montevecchi
}

Source: The Condor, 103(1):98-107. 2001.

Published By: Cooper Ornithological Society

DOI: http://dx.doi.org/10.1650/0010-5422(2001)103[0098:RBOSSG]2.0.CO;2

URL: http://www.bioone.org/doi/full/10.1650/0010-5422\%282001\%29103\%5B0098\%3ARBOSSG

$\% 5 \mathrm{D} 2.0 . \mathrm{CO} \% 3 \mathrm{~B} 2$

BioOne (www.bioone.org) is a nonprofit, online aggregation of core research in the biological, ecological, and environmental sciences. BioOne provides a sustainable online platform for over 170 journals and books published by nonprofit societies, associations, museums, institutions, and presses.

Your use of this PDF, the BioOne Web site, and all posted and associated content indicates your acceptance of BioOne's Terms of Use, available at www.bioone.org/page/terms_of_use.

Usage of BioOne content is strictly limited to personal, educational, and non-commercial use. Commercial inquiries or rights and permissions requests should be directed to the individual publisher as copyright holder. 


\title{
REPRODUCTIVE BIOLOGY OF SABINE'S GULL IN THE CANADIAN ARCTIC ${ }^{1}$
}

\author{
IAIN J. Stenhouse ${ }^{2}$ \\ Biopsychology Programme, Memorial University of Newfoundland, St. John's, \\ Newfoundland A1B 3X9, Canada \\ H. GRANT GILCHRIST \\ Canadian Wildlife Service, Northern Conservation Division, 5204 50th Avenue, Yellowknife, \\ Northwest Territories X1A 1E2, Canada \\ William A. MonteveCCHI \\ Biopsychology Programme, Memorial University of Newfoundland, St. John's, \\ Newfoundland A1B 3X9, Canada
}

\begin{abstract}
We studied the reproductive biology of Sabine's Gulls (Xema sabini) breeding on Southampton Island, in the eastern Canadian Arctic, from May to August in 1998 and 1999, and compared our results to information collected from the same region in 1980. Breeding phenology was 10 days earlier in 1998 than in these other years, and reflects an earlier onset of snowmelt in that year. Nests were dispersed, with a density of 7.6 to 8.7 nests per $\mathrm{km}^{2}$. Sabine's Gulls exhibited strong interannual fidelity to breeding sites. Mean clutch size was lower in 1999 than 1998, and lower in both these years than in 1980. Hatching success was $63 \%$ in 1998, but only $21 \%$ in 1999 due to increased predation, most likely by arctic fox (Alopex lagopus). Adult gulls and chicks abandoned nest-sites within a few hours of the hatching of the last chick and relocated to coastal ponds, where adults continued to attend chicks. In comparisons of the reproductive biology of Sabine's Gull to closely related "tern-like" gull species and other "black-headed" gulls, Sabine's Gull showed a number of distinct ecological and behavioral differences and represents an ecological outlier within the Laridae.
\end{abstract}

Key words: breeding phenology, gull phylogeny, nesting density, nest predation, reproductive biology, Sabine's Gull, Xema sabini.

\section{INTRODUCTION}

Gull species are among the most widely studied of birds, and research has been directed at a variety of behavioral, ecological and evolutionary issues. The large Larus species have received much of the research attention around the world, and their breeding ecology is generally well documented (Southern 1987). The reproductive biology of a number of small gull species, however, remains poorly understood.

A recent reconstruction of phylogenetic relationships within the gulls, based on structural characteristics, grouped kittiwakes (Rissa spp.), fork-tailed gulls (Xema and Creagrus) and the Ivory Gull (Pagophila eburnea) in a distinct lineage (Chu 1998). The kittiwakes have been well studied in both the Palearctic and the Nearctic (Byrd and Williams 1993, Baird 1994); however,

\footnotetext{
${ }^{1}$ Received 25 May 2000. Accepted 28 September 2000.

${ }^{2}$ E-mail: iansten@ play.psych.mun.ca
}

little is known about the ecology of the other three "tern-like" genera. These three genera are each represented by a single species. The Sabine's Gull (Xema sabini) and Ivory Gull have circumpolar distributions and breed at high latitudes, while the Swallow-tailed Gull (Creagrus furcatus) breeds on the Galápagos Islands.

Since it was first scientifically documented in 1818, Sabine's Gull has rarely been studied, largely due to its remote Arctic breeding locations. It is also a trans-equatorial migrant which spends most of its life at sea, and its wintering areas have only been documented in the last few decades (Zoutendyk 1965, 1968). As well as being phylogenetically distinct, Sabine's Gull is considered highly atypical in many aspects of its behavior compared to other gulls (Brown et al. 1967). For example, it shows several foraging strategies characteristic of shorebirds, such as pattering on mud and picking at the substrate like plovers (Bent 1921), and spinning on the surface of ponds and picking at the water sur- 


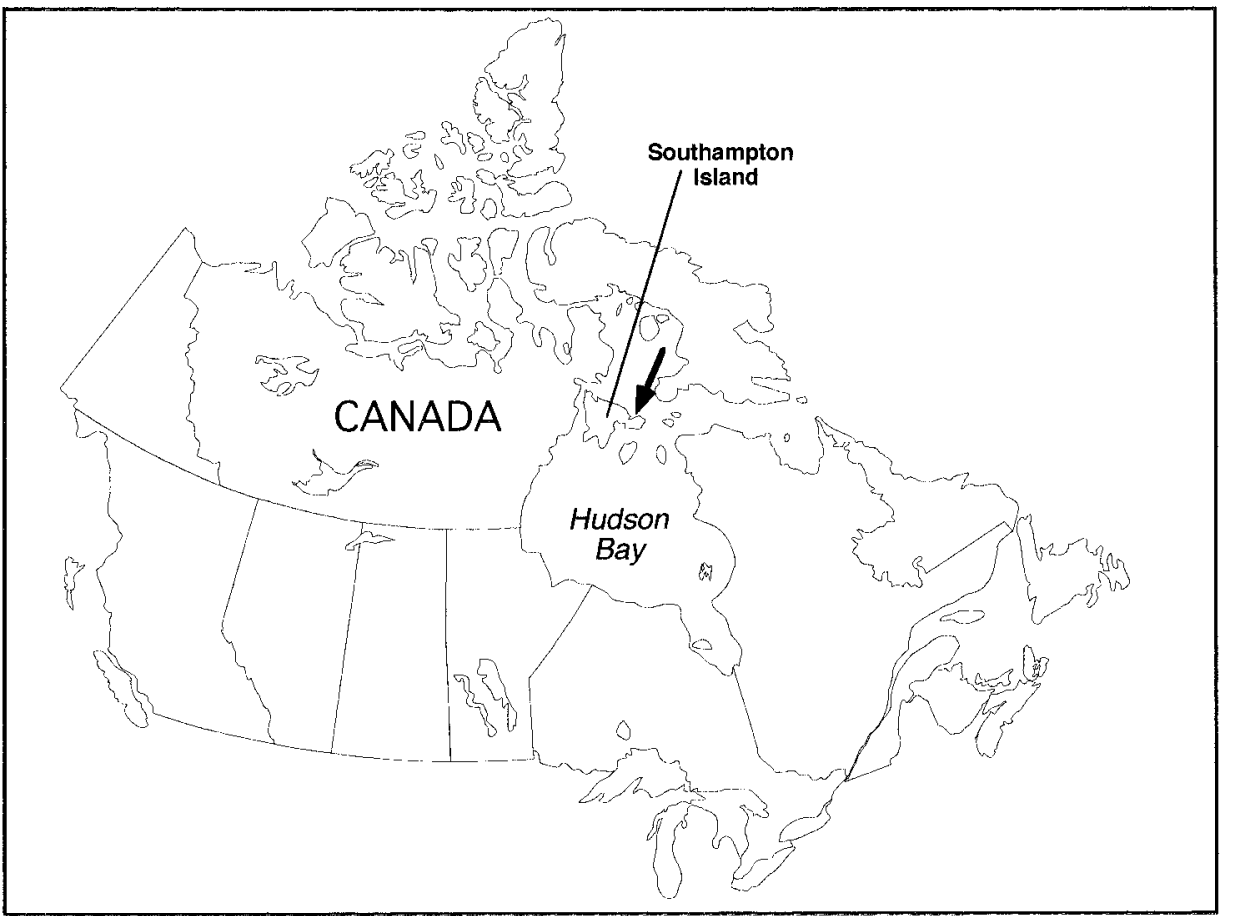

FIGURE 1. Location of Southampton Island, Canada, with the general study area at East Bay marked by heavy arrow.

face like phalaropes (Brown et al. 1967). Sabine's Gulls also exhibit a distraction display when potential predators approach their eggs or chicks, more typical of many shorebirds and skuas, suggesting that they have evolved in environments where predation pressures are intense.

Sabine's Gulls also have an unusual molt chronology compared to most other gulls. Young Sabine's Gulls retain their full juvenal plumage through their first autumn, and do not start the post-juvenal head and body molt into first-winter plumage until they reach their wintering areas (Grant 1986). Adult Sabine's Gulls also undergo a complete molt in spring, prior to their northward migration, and a partial molt in autumn, on arrival at their wintering area; the reverse pattern of most other gulls (Grant 1986). The timing of molt may provide insights into seasonal energetic constraints of this long-distance migrant.

In this study, we detail the reproductive biology of Sabine's Gulls in East Bay, on Southampton Island, Nunavut, in the eastern Canadian Arctic. A previous study of the foraging interactions between Arctic Terns (Sterna paradi- saea) and Sabine's Gulls was carried out in East Bay in 1980 (Abraham 1982), and these data provide the first opportunity for long-term comparisons in this species. Specifically, we compare reproductive parameters in 1998 and 1999, and with 1980 where comparable data exist. Finally, we compare aspects of the breeding ecology of Sabine's Gull with the other "tern-like" gull species, believed to be closely related (Chu 1998), as well as small "black-headed" gulls (Little Gull, Larus minutus; Common Blackheaded Gull, L. ridibundis; Mediterranean Gull, L. melanocephalus), and other small Arctic breeders (Ross' Gull, Rhodostethia rosea; Arctic Tern) and explore ecological similarities and differences among these species.

\section{METHODS}

\section{STUDY AREA}

East Bay Migratory Bird Sanctuary $\left(64^{\circ} 01^{\prime} \mathrm{N}\right.$, $\left.81^{\circ} 47^{\prime} \mathrm{W}\right)$ encompasses an area of $1,166 \mathrm{~km}^{2}$ on Southampton Island, Nunavut, Canada (Fig. 1). The area is a flat, low-lying, boggy tundra, with a complex of brackish and freshwater ponds. 
Despite being located at a subarctic latitude, East Bay is influenced in its ecological and physical characteristics by the deep, cold waters of Foxe Channel. Land-fast sea ice remains in East Bay well into July and daily minimum temperatures are close to freezing throughout the summer months.

\section{DATA COLLECTION}

Fieldwork was conducted from late May to mid August in 1998 and 1999. Reproductive success was followed in all nests located within a $2 \times$ 2-km study area on the southern shore of East Bay. In addition, a single visit was made each year to a second $2 \times 2-\mathrm{km}$ study area in East Bay approximately $8 \mathrm{~km}$ to the east (see Abraham 1982). In the primary study area, nests were located by searching on foot and were visited either daily or every second day until the clutch was complete. Nests were visited on average every three days during incubation and daily during the hatching period.

Nest-site characteristics were recorded for each nest when first found, including location (island or pond edge), aspect (direction of slope), distance from nest edge to the nearest water, direction of the middle of the nearest pond, and distance to nearest conspecific neighbor. In 1998, the distance between nests was measured along the ground to the nearest $1 \mathrm{~m}$ with a 20-m tape. In 1999, nests were plotted on a 1:50,000 aerial photograph, internest distances were calculated to the nearest $5 \mathrm{~m}$ from the photograph, and $30 \%$ of measures were ground-truthed following the 1998 procedure. Eggs were measured to the nearest $0.1 \mathrm{~mm}$ with vernier calipers and weighed to the nearest $0.5 \mathrm{~g}$ with a 60-g Pesola scale. Egg volumes were calculated using the formula $\mathrm{V}=0.4866 \times$ length $\times$ breadth $^{2}$ (Coulson 1963). Hatching success was calculated as the number of eggs hatched divided by the number of eggs laid. An egg was considered depredated if it disappeared from a nest cup prior to hatch or was found broken or punctured.

Adults were captured at the nest during incubation with a simple wire mesh fall trap (Bub 1991). Most trapped birds returned to incubate within a few minutes of release, and no nest desertion occurred as a result of trapping. Adults were marked with a numbered metal band and a unique combination of three colored plastic bands. Chicks were marked at the nest imme- diately after hatching, with a numbered metal band and a single colored plastic band (identifying year of hatch). In a few cases, small chicks lost their metal bands, but all appeared to retain their single color band. After leaving the nest, chicks were captured by hand, usually when swimming across shallow ponds. For adults and chicks, the length of the tarsus and exposed culmen were measured to the nearest $0.1 \mathrm{~mm}$ using vernier calipers, and weight was measured to the nearest $1 \mathrm{~g}$ with a Pesola scale (300-g scale for adults, 100-g scale for chicks). Wing length was measured to the nearest $1 \mathrm{~mm}$ in adults and in chicks of 5 days and older, when primaries broke through feather sheaths.

\section{STATISTICAL ANALYSIS}

Goodness of fit was examined using the $G$-test of independence, employing the Williams' correction for $2 \times 2$ contingency tables (Sokal and Rohlf 1995). Relationships between variables and between years were examined using ANOVA and Mann-Whitney $U$-tests (DataDesk 4.2, Data Description Inc., Ithaca, NY). The residuals from the regression of weight on tarsus were used as an index of condition in breeding adults. Throughout, error distributions were examined for homogeneity, normality, and independence of residuals, and found to be acceptable. Values reported below are means $\pm \mathrm{SD}$, unless otherwise stated, and statistical significance is recognized at $P \leq 0.05$.

\section{RESULTS}

\section{BREEDING PHENOLOGY}

Previous studies suggest that arrival at the breeding ground and the general timing of breeding in Sabine's Gulls is highly dependent on environmental conditions, particularly ice and snowmelt (Sutton 1932, Abraham 1986). In this study, nest building and egg laying were dependent on the timing of snowmelt, and commenced as soon as conditions allowed (i.e., once freshwater ponds formed and tundra was exposed on the breeding territory) after the pair bonded or reunited.

At East Bay, adults were first observed in breeding areas on 7 June 1998 and 10 June 1999 (Table 1). The general phenology of breeding in 1999 was similar to that observed at East Bay in 1980 (Abraham 1982, 1986), suggesting that 1998 was an early year. The onset of snowmelt and initiation of breeding were both approxi- 
TABLE 1. Range of breeding phenologies of Sabine's Gulls at East Bay, Southampton Island, during three years.

\begin{tabular}{|c|c|c|c|c|c|}
\hline Year & $\begin{array}{l}\text { First } \\
\text { gulls in } \\
\text { study } \\
\text { area }\end{array}$ & $\begin{array}{l}\text { Onset of } \\
\text { snowmelt s }\end{array}$ & $\begin{array}{c}90 \% \\
\text { snowmelt }\end{array}$ & $\begin{array}{c}\text { Clutch } \\
\text { initiation }\end{array}$ & $\begin{array}{c}\text { Hatching } \\
\text { dates }\end{array}$ \\
\hline $1980^{1}$ & 12 June & e 18 June & 24 June & $\begin{array}{l}23 \text { June } \\
-3 \text { July }\end{array}$ & $\begin{array}{c}14-22 \\
\text { July }\end{array}$ \\
\hline 1998 & 7 June & 4 June & 12 June & $\begin{array}{c}14-20 \\
\text { June }\end{array}$ & $\begin{array}{l}6-12 \\
\text { July }\end{array}$ \\
\hline 1999 & 10 June & e 14 June & 21 June & $\begin{array}{c}23-27 \\
\text { June }\end{array}$ & $\begin{array}{c}15-19 \\
\text { July }\end{array}$ \\
\hline
\end{tabular}

${ }^{1}$ From Abraham 1986.

mately 10 days later in 1980 and 1999 than in 1998 (Table 1).

The first egg was laid on 14 June in 1998 and on 23 June in 1999 (Table 1). The median dates of clutch initiation were 15 June $(n=18)$ in 1998 and significantly later on 25 June $(n=13)$ in 1999 (Mann-Whitney $U$-test, $Z=-4.8, P<$ $0.001)$. Laying and hatching periods were somewhat contracted in 1999 compared to 1998, and in both years compared to 1980 (Table 1).

\section{NESTING DENSITY}

At the main study area, nesting density was 7.6 nests per $\mathrm{km}^{2}$ in 1998 , and 8.7 nests per $\mathrm{km}^{2}$ in 1999. The mean distance to the nearest conspecific neighbor was $107 \mathrm{~m}$ (range $=32-214 \mathrm{~m}$, $n=21$ ) in 1998 , and $101 \mathrm{~m}$ (range $=21-158$ $\mathrm{m}, n=26)$ in 1999 , and did not differ between years $\left(F_{1,46}=0.17, P=0.68\right)$. Generally, nests were evenly distributed at East Bay. However, in one location at the secondary study area, a few pairs nested close together on a small mossy island: three pairs in 1998 (mean internest distance $=5.9 \mathrm{~m}$ ) and two pairs in 1999 (internest distance $=3.5 \mathrm{~m}$ ).

\section{NEST-SITE CHARACTERISTICS}

On Southampton Island, Sabine's Gulls generally formed their nest cups in soft moss on the edges of ponds or on small islands within ponds. The nest cup was usually bare, but sometimes was lined with a few goose feather quills or pieces of dried seaweed. Nests often remained visibly damp. Nest cups were occasionally found on a slightly raised hummock of moss, perhaps providing improved drainage.

The study area is extremely flat and all nests were completely exposed, i.e., not associated with any type of cover or aspect. Nests were always located close to water, although the mean distance to nearest water was significantly greater in $1999(1.1 \pm 1.4 \mathrm{~m}, n=26)$ than in 1998 $\left(0.4 \pm 0.4 \mathrm{~m}, n=23 ; F_{1,48}=5.26, P=0.03\right)$. The direction of nearest water was also much more variable in $1999(24 \% \mathrm{~N}, 12 \% \mathrm{E}, 29 \% \mathrm{~S}$, $35 \% \mathrm{~W})$ than in $1998(0 \% \mathrm{~N}, 4 \% \mathrm{E}, 46 \% \mathrm{~S}$, $50 \% \mathrm{~W}$ ), when nests were mainly found on the northern and eastern shores of ponds.

Sabine's Gulls displayed strong fidelity to their breeding area. Of 13 marked pairs, 11 nested close to their 1998 sites in 1999 (mean distance moved $=71 \mathrm{~m}$, range $=0-125 \mathrm{~m}, n=$ 11), with two of these pairs returning to the same nest cup in 1999 that they had used in 1998. Of the two pairs that did not nest close to their previous sites, the eggs of the pair that moved farthest $(415 \mathrm{~m})$ were depredated early in 1998, while the other pair (which moved 210 m) hatched three chicks in 1998

\section{EGGS AND CLUTCH SIZE}

The mean weight of freshly laid eggs was 24.7 $\pm 1.5 \mathrm{~g}(n=31)$ in 1998 and $24.4 \pm 2.1 \mathrm{~g}(n$ $=44$ ) in 1999. Mean weight of eggs was, however, greater in both 1998 and 1999 than in 1980 (22.3 $\pm 0.4 \mathrm{~g}, n=25$; Abraham 1986). Overall, in 1998 and 1999, mean egg length was $45.2 \pm$ $1.7 \mathrm{~mm}(n=144)$ and mean egg breadth was $32.6 \pm 0.8 \mathrm{~mm}(n=144$; Table 2$)$. Mean egg volume was $23.2 \pm 1.5 \mathrm{cc}(n=58)$ in 1998 and $23.5 \pm 1.8 \mathrm{cc}(n=86)$ in 1999 , and did not differ among clutch sizes $\left(F_{1,143}=2.3, P=\right.$ $0.08)$ or between years $\left(F_{1,143}=3.1, P=0.08\right)$, and there was no interaction between year and clutch size $\left(F_{1,143}=1.1, P=0.3\right)$.

Mean clutch size was $2.6 \pm 0.6(n=27)$ in 1998 and $2.4 \pm 0.6(n=37)$ in 1999 , lower in

TABLE 2. Mean clutch size ( \pm SD) and morphometrics of freshly laid Sabine's Gull eggs during three years at East Bay, Southampton Island.

\begin{tabular}{|c|c|c|c|c|}
\hline Year & Clutch size & $\underset{(\mathrm{mm})}{\text { Egg length }}$ & $\underset{(\mathrm{mm})}{\text { Egg breadth }}$ & $\underset{(\mathrm{g})}{\operatorname{Egg} \text { mass }}$ \\
\hline & $\begin{array}{c}2.77 \pm 0.1 \\
(n=19)\end{array}$ & - & - & $\begin{array}{c}22.3 \pm 0.4 \\
(n=25)\end{array}$ \\
\hline 1998 & $\begin{array}{c}2.56 \pm 0.6 \\
(n=27)\end{array}$ & $\begin{array}{c}44.9 \pm 1.5 \\
(n=43)\end{array}$ & $\begin{array}{c}32.5 \pm 0.8 \\
(n=43)\end{array}$ & $\begin{array}{c}24.7 \pm 1.5 \\
(n=31)\end{array}$ \\
\hline 1999 & $\begin{array}{c}2.38 \pm 0.6 \\
(n=37)\end{array}$ & $\begin{array}{c}45.4 \pm 1.8 \\
(n=44)\end{array}$ & $\begin{array}{c}32.7 \pm 0.8 \\
(n=44)\end{array}$ & $\begin{array}{c}24.4 \pm 2.1 \\
(n=44)\end{array}$ \\
\hline
\end{tabular}

${ }^{1}$ From Abraham 1986. 
TABLE 3. Reproductive performance of Sabine's Gulls during three years at East Bay, Southampton Island.

\begin{tabular}{lccc}
\hline \hline \multicolumn{1}{c}{ No. of } & $1980^{1}$ & 1998 & 1999 \\
\hline Clutches followed & 19 & 23 & 25 \\
Eggs laid & 53 & 60 & 57 \\
Eggs depredated & 3 & 16 & 43 \\
Eggs abandoned & 2 & 3 & 2 \\
Eggs addled & 4 & 3 & 0 \\
Eggs hatched & 44 & 38 & 12 \\
Eggs hatched per clutch & 2.31 & 1.65 & 0.48 \\
Hatching success (\%) & 83 & 63 & 21 \\
\hline
\end{tabular}

${ }^{1}$ From Abraham 1986.

both years than in 1980 (Table 2). The proportions of 1, 2, and 3-egg clutches was significantly different between 1998 and $1999\left(G_{2}=\right.$ $6.3, P=0.04)$, with a greater proportion of 3 egg clutches $(70 \%)$ in 1998 and 2-egg clutches $(56 \%)$ in 1999 , and a similar proportion of 1egg clutches $(<10 \%)$ in both years.

\section{INCUBATION BEHAVIOR}

Incubation begins with the laying of the first egg (Abraham 1986) and, in this study, both members of the pair were observed to attend the nest and share incubation. However, it is not known if there are differences in nest attendance between males and females. Three brood patches, two lateral and one median, were observed in both sexes. Eggs were often exposed while adults foraged nearby, and occasionally eggs were found completely unattended with no adults in the vicinity. Over both years of the study, laying dates were certain for a total of 18 eggs, of which 13 hatched on day 21 and 5 on day 22 of incubation.

\section{HATCHING SUCCESS AND CAUSES OF MORTALITY}

Hatching success (eggs hatched divided by eggs laid) was 63\% (38 of 60) in 1998 and $21 \%$ (12 of 57) in $1999\left(G_{1}=21.8, P<0.001\right.$; Table 3$)$. Hatching success in both years of this study was lower than that found in 1980 (83\%, Abraham 1986). The difference in hatching success between 1998 and 1999 reflects a marked increase in predation in 1999, most likely by arctic foxes (Alopex lagopus), which were observed on the study area much more frequently in that year. In $1998,27 \%$ of eggs (16 of 60) were lost to predation, and in 1999, $75 \%$ of eggs (43 of 57) were lost $\left(G_{1}=28.7, P<0.001\right.$; Table 3$)$. Successful pairs produced an average of $2.5(n=$ 15) chicks in 1998 and $2.0(n=6)$ chicks in 1999.

\section{POSTNATAL DEVELOPMENT}

In 1998 and 1999, the mean weight of newly hatched chicks was $24.2 \pm 5.2 \mathrm{~g}(n=47)$. Newly hatched chicks had a mean tarsus length of $18.4 \pm 0.7 \mathrm{~mm}$ and a mean exposed culmen of $9.4 \pm 0.5 \mathrm{~mm}(n=47)$. Chicks were downy at hatch, with the typical striped pattern of gull chicks, and legs and bill were pale pink. Down was rusty red on upper parts and white on belly and underwing. The down faded to a paler fawn color and the bill tip and legs darkened at around three days old. The egg tooth was retained until five or six days old. Chicks were able to leave the nest as soon as they were dry, walking and swimming away from the nest at the slightest sign of a threat, and could hide under a rock or along a pond edge.

Adults led their broods away from the nest site within hours of the last chick hatching, and occasionally left a small chick or pipped egg behind. In East Bay, family groups moved to saltwater ponds along the edge of the bay, where they became extremely difficult to monitor. Family groups appeared to stay together, and all adults in the area came together to mob potential predators. Chicks were highly mobile, could run, swim, and hide from threats, and were easily lost in the confusion of mobbing. Chicks of at least one family, however, were found repeatedly in the same area and appeared to return to the same location after disturbances. This level of high mobility away from the nest is atypical for young gull chicks, prohibits detailed study of chick growth and fledgling development, and prevents an accurate measure of fledging success.

\section{ADULT MORPHOMETRICS}

Breeding adults were measured during incubation in both years. Structural measures did not differ between years. Adults had a mean tarsus length of $33.6 \pm 1.3 \mathrm{~mm}(n=26)$ in 1998 and $33.4 \pm 1.3 \mathrm{~mm}(n=18)$ in $1999\left(F_{1,42}=0.3\right.$, $P=0.56)$, and a mean culmen length of $25.0 \pm$ $1.3 \mathrm{~mm}(n=26)$ in 1998 and $24.4 \pm 1.0 \mathrm{~mm}$ $(n=18)$ in $1999\left(F_{1,42}=2.7, P=0.11\right)$. Both mean weight and wing length differed between years, however, with a mean weight of $198.1 \pm$ 
$10.4 \mathrm{~g}(n=23)$ in 1998 and $179.5 \pm 10.3 \mathrm{~g}(n$ $=18)$ in $1999\left(F_{1,39}=32.8, P<0.001\right)$, and a mean wing length of $280.6 \pm 7.2 \mathrm{~mm}(n=23)$ in 1998 and $274.2 \pm 9.6 \mathrm{~mm}(n=18)$ in 1999 $\left(F_{1,39}=6.0, P=0.02\right)$. Controlling for body size, based on the regression of weight on tarsus measures, breeding adults were found to be in poorer condition during incubation in 1999 than in $1998\left(F_{1,39}=32.9, P<0.001\right)$.

\section{COMPARISON WITH OTHER SMALL GULLS}

Sabine's Gulls show distinct differences from gull species believed to be closely related (i.e., Black-legged Kittiwake, Rissa tridactyla; Ivory Gull; and Swallow-tailed Gull; Chu 1998) and some similarities with other small "black-headed" gulls (Little Gull, Common Black-headed Gull, Mediterranean Gull; Table 4). Sabine's Gull has a circumpolar distribution but is largely restricted to the Low Arctic during breeding. Of the species in the "related" grouping, only the Black-legged Kittiwake has a broad breeding distribution. Sabine's Gull is the only exclusively ground-nesting species in the group, and the only one which often nests solitarily. These characteristics are shared, however, with the other small black-headed gulls, except the Mediterranean Gull, which nests at high densities.

Compared to the other species in Chu's (1998) grouping, Sabine's Gull matures earlier; it is believed to start breeding at 2 years (Day et al. in review), but this characteristic is shared with the other small black-headed gulls. Sabine's Gull is a small bird, some 50-55\% lighter than the Black-legged Kittiwake. The ratio of egg mass to female body mass in Sabine's Gull is similar to the other species in Chu's (1998) group; however, the higher clutch size in Sabine's Gull may be a greater drain on female nutrient reserves (clutch mass up to $36 \%$ of female body mass) than in the other species. Only the Little Gull and Common Black-headed Gull show a similar or higher egg mass to female body mass ratio and a similar mean clutch size to Sabine's Gull (Table 4). Sabine's Gull exhibits a relatively short breeding season with contracted incubation and fledging periods compared to the species in Chu's (1998) grouping, but, again, is similar to the other small black-headed gulls. In addition, Sabine's Gull has a much longer migration than any of the gull species compared in Table 4, but is similar to the Arctic Tern in this respect, with an annual round trip migration of approximately $25,000 \mathrm{~km}$.

\section{DISCUSSION}

At East Bay, nests were evenly dispersed, except in one case where two to three pairs nested close together on a small island. Although there appeared to be no shortage of safe island sites, the distance of the island from shore and/or the pond depth may play a role in whether an island actually provides safety from mammalian predators. Contrary to early reports on this species (Bent 1921, Bray 1943, Salomonsen 1951, Larson 1960, Bannerman 1962), Sabine's Gulls at East Bay were generally not colonial, nor did they nest in close association with Arctic Terns. The existence of the small island group, however, suggests that this species is semi-colonial on occasion.

In 1999, the general phenology of breeding at East Bay was similar to that observed in 1980. However, breeding in 1998 was considerably earlier than in either of these years in all respects, and, in 1998, snowmelt began approximately 10 days earlier than 1980 or 1999 . In 1998, Sabine's Gulls arrived on the breeding ground earlier, and both nest initiation and hatch were approximately 10 days earlier. This suggests that the onset of snowmelt partly determines the initiation of breeding, as would be expected for ground-nesters in the Arctic.

Nests of Sabine's Gulls at East Bay were similar to those previously described for this species (Ilyichev and Zubakin 1988). Nest cups were placed on damp mossy areas on pond edges. In northeast Greenland, however, nests were found on small patches of vegetation on slopes of eroded bedrock and gravel banks (Forchhammer and Maagaard 1991). Year-to-year variation in climatic conditions in East Bay, particularly prevailing wind direction, may have some effect on the precise positioning of nests in relation to the nearest water. In stormy conditions, nests at East Bay can be washed over by spray from pond edges or surrounded by foam blown from the surface of ponds (pers. obs.).

At East Bay, clutch size was lower in 1999 than 1998. This may be the result of an increased period between arrival and nesting in 1999 due to the later onset of snowmelt and exposure of tundra. Incubating adults were also in poorer condition in 1999. As has been suggested for Arctic-breeding geese (Ankney and McInnes 
104 IAIN J. STENHOUSE ET AL.

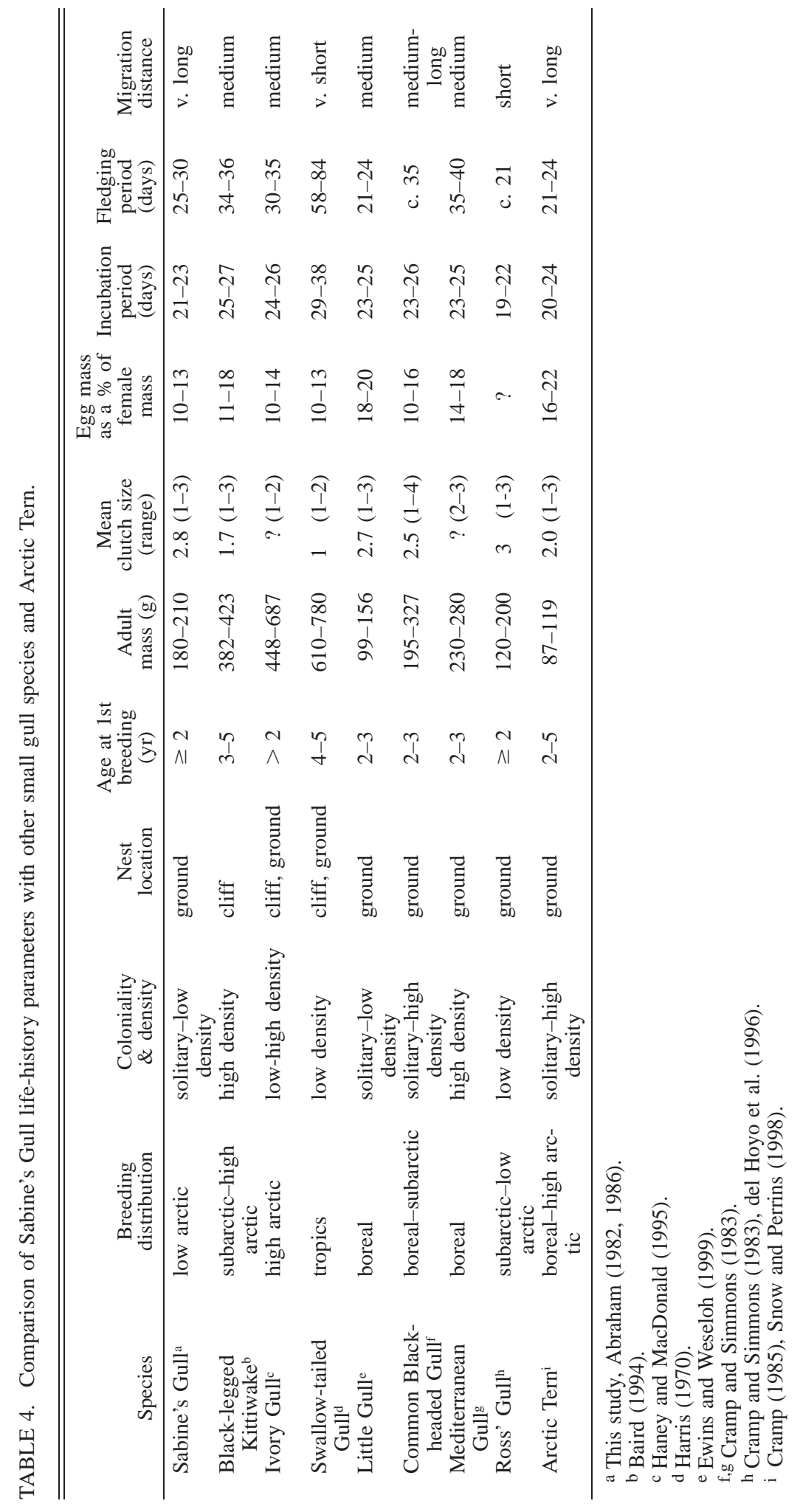


1978, Davies and Cooke 1983, Ebbinge and Spaans 1995), Sabine's Gulls may have to rely on their nutrient reserves while waiting to nest and, therefore, females have less reserve resources available for egg production in late years. However, even though breeding phenology was similar in 1980 and 1999, clutch size and hatching success were higher in 1980 than in the 1990s. The extent of reserve resources available for egg production is likely the combined result of conditions experienced (1) prior to migration, (2) during migration, and (3) during the pre-laying period at the breeding ground.

The reverse molt pattern exhibited by $\mathrm{Sa}-$ bine's Gulls has some interesting implications. The environmental conditions experienced during the complete molt in spring, prior to migration, may influence feather growth (i.e., wing length), whereas body mass may reflect the conditions experienced during migration or upon arrival at the breeding site. Thus, wing length and body mass may represent different indices of condition, and in years of particularly poor conditions during late winter and early spring, both would be expected to be compromised. Interestingly, when controlled for size using a structural measure (tarsus), both wing length and body mass were indeed lower in 1999 than 1998, suggesting that conditions were generally poor during the winter of 1998-1999 as well as the spring and early summer of 1999.

Few eggs were depredated in 1980 compared with the 1990s, and in 1980 abandoned eggs and dead chicks remained undisturbed on the study area despite the presence of avian and mammalian predators (Abraham 1986). This suggests that the predators and scavengers in the area were not food-stressed in 1980. Predation rates on nesting birds can vary considerably in Arctic tundra environments (Summers and Underhill 1987). In some years arctic foxes depend almost entirely on the eggs and young of nesting birds (Larson 1960, Sklepkovych and Montevecchi 1996). Occasional, extreme predation of this kind has been observed in several Arctic breeding bird species (Summers 1986, Underhill 1987, Underhill et al. 1989) and is generally related to annual variation in alternative prey populations (i.e., rodents; Summers and Underhill 1987, Sklepkovych and Montevecchi 1996, Summers et al. 1998). As yet, however, it is not clear if the reproductive success of Sabine's
Gulls in East Bay is influenced by the availability of alternative prey for mammalian predators.

Although Abraham (1986) found that Sabine's Gulls in East Bay left their nests soon after hatch, she did not report their movements beyond this stage. Our observations of families moving to large saltwater ponds along the edge of the bay immediately after hatch, and the fact that chicks were found in the same location on several occasions, supports Forchhammer and Maagaard's (1991) suggestion that Sabine's Gulls establish small post-hatching territories.

Some aspects of the reproductive biology of Sabine's Gulls are typical of larger gulls: (1) they have simple nest-site requirements, (2) they display a strong fidelity to their breeding areas, and (3) they generally lay three eggs (except in Greenland, Forchhammer and Maagaard 1991). However, some aspects of the reproductive biology of Sabine's Gulls are clearly atypical of most gulls. The early abandonment of the nest, relocation of the entire family, and establishment of post-hatching territories are particularly notable. Thus, our findings support the conclusion that Sabine's Gull represents an ecological outlier within the gulls, even when compared to species considered closely related.

Sabine's Gulls' relatively short incubation and fledging periods, their departure from nests immediately after hatch, and their establishment of post-hatching territories may be adaptations to the ephemeral nature of their aquatic and terrestrial invertebrate prey during the breeding season. However, Forchhammer and Maagaard (1991) did not observe adults foraging in posthatching territories. Alternatively, congregating on larger coastal ponds may facilitate escape or concealment of chicks from predators and enhance the ability of Sabine's Gulls to collectively mob predators. Another explanation, which does not exclude the previous one, is that these behaviors may reflect intense pressure to leave the breeding area as soon as possible, and switch to marine prey in preparation for their migration to wintering areas in the southern hemisphere.

Based on this species' ecological differences from other gulls, we support the retention of Sabine's Gull in a single genus (Xema). For similar reasons, however, it could be argued that the other species in Chu's (1998) grouping (Rissa, Creagrus and Pagophila) should remain in separate genera. The general similarities of Sabine's Gull with other small black-headed gulls cer- 
tainly calls into question gull groupings based on morphometrics alone. Clearly, the question of whether current groupings actually relate to phylogeny or to convergent evolution remains and can only be resolved with a comprehensive genetic analysis of the entire Laridae.

\section{ACKNOWLEDGMENTS}

We are extremely grateful to the community of Coral Harbour for encouragement and permission to work in East Bay. We are indebted to Rachel Bryant, Karen Truman, Karel Allard and Josiah Nakoolak for assistance in the field, and we thank Tony Gaston, Daniel Oro, Gilles Chapdelaine and Greg Robertson for valuable reviews and comments that greatly improved the manuscript. Research was supported by the Northern Conservation Division of Canadian Wildlife Service (HGG), Memorial University of Newfoundland (Graduate Fellowship to IJS) and NSERC (Individual Operating Grant-WAM).

\section{LITERATURE CITED}

ABraham, D. M. 1982. Resource partitioning between Sabine's Gulls and Arctic Terns during the breeding season. M.Sc. thesis, Univ. Western Ontario, London, Ontario, Canada.

ABraham, D. M. 1986. Observations on the breeding biology of Sabine's Gulls (Xema sabini). Can. J. Zool. 64:898-903.

AnKNey, C. D., AND C. D. McInNEs. 1978. Nutrient reserves and reproductive performance of female Lesser Snow Geese. Auk 95:459-471.

BANnerman, D. A. 1962. The birds of the British Isles. Vol. 2. Oliver \& Boyd, Edinburgh, UK.

BAIRD, H. P. 1994. Black-legged Kittiwake (Rissa tridactyla). In A. Poole and F. Gill [EDS.], The birds of North America, No. 92. The Academy of Natural Sciences, Philadelphia, and The American Ornithologists' Union, Washington, DC.

Bent, A. C. 1921. The life histories of North American gulls and terns. U.S. Natl. Mus. Bull. 133.

BuB, H. 1991. Bird trapping and bird banding: a handbook for trapping methods all over the world. Cornell University Press, NY.

BRAY, R. 1943. Notes on the birds of Southampton Island, Baffin Island, and Melville Peninsula. Auk 60:504-536.

Brown, R. G. B., N. G. Blurton-Jones, And D. J. T. Hussell. 1967. The breeding behaviour of Sabine's Gull (Xema sabini). Behaviour 28:110-140.

Byrd, G. V., AND J. C. Williams. 1993. Red-legged Kittiwake (Rissa brevirostris). In A. Poole and F. Gill [EDS.], The birds of North America, No. 60. The Academy of Natural Sciences, Philadelphia, and The American Ornithologists' Union, Washington, DC.

Chu, P. C. 1998. A phylogeny of the gulls (Aves: Larinae) inferred from osteological and integumentary characters. Cladistics 14:1-43.

Coulson, J. C. 1963. Egg size and shape in the kittiwake (Rissa tridactyla) and their use in estimating age composition of populations. Proc. Zool. Soc. Lond. 140:211-227.

Cramp, S. 1985. Birds of the western Palearctic. Vol. 4. Oxford Univ. Press, Oxford.

Cramp, S., And K. E. L. Simmons. 1983. Birds of the western Palearctic. Vol. 3. Oxford Univ. Press, Oxford.

Davies, J. C., And F. Cooke. 1983. Annual nesting productivity in Snow Geese: prairie droughts and Arctic springs. J. Wildl. Manage. 47:291-296.

Day, R. H., I. J. Stenhouse, and H. G. Gilchrist. In review. Sabine's Gull (Xema sabini). In A. Poole and F. Gill [EDS.], The birds of North America. The Birds of North America, Inc., Philadelphia, PA.

del Hoyo, J., A. Elliott, and J. Sargatal. 1996. Handbook of the birds of the world. Vol. 3. Lynx Edicions, Barcelona.

Ebbinge, B. S., And B. SpaAns. 1995. The importance of body reserves accumulated in spring staging areas in the temperate zone for breeding in Darkbellied Brent Geese (Branta b. bernicla) in the High Arctic. J. Avian Biol. 26:105-113.

Ewins, P. J., AND D. V. C. Weseloh. 1999. Little Gull (Larus minutus). In A. Poole and F. Gill [EDS.], The birds of North America, No. 428. The Academy of Natural Sciences, Philadelphia, and The American Ornithologists' Union, Washington, DC.

ForChHAMmer, M., AND L. MAAGAARD. 1991. Breeding biology of Sabine's Gull (Larus sabini) in northeast Greenland. Dansk. Orn. Foren. Tidsskr. 85:53-62.

GRANT, P. J. 1986. Gulls: a guide to identification. 2nd ed. Buteo Books, Vermillion, SD.

Haney, J. C., AND S. D. MacDonald. 1995. Ivory Gull (Pagophila eburnea). In A. Poole and F. Gill [EDS.], The birds of North America, No. 175. The Academy of Natural Sciences, Philadelphia, and The American Ornithologists' Union, Washington, DC.

HaRris, M. P. 1970. Breeding biology of the Swallowtailed Gull, Creagrus furcatus. Auk 87:215-243.

IlyicheV, V. D., AND V. A. Zubakin. 1988. Birds of the USSR: Larids. Publishing House Nauka, Moscow.

LARSON, S. 1960. On the influence of the Arctic fox (Alopex lagopus) on the distribution of Arctic birds. Oikos 11:276-305.

Parmelee, D. F., H. A. Stephens, and R. H. Schmidt. 1967. Birds of southeastern Victoria Island and adjacent small islands. Natl. Mus. Can. Bull. No. 222.

SAlomonsen, F. 1951. Fuglene på Grønland. Rhodos, Copenhagen.

Sklepkovych, B. O., AND W. A. Montevecchi. 1996. Food availability and food hoarding behaviour by Red and Arctic Foxes. Arctic 49:228-234.

Snow, D. W., AND C. M. Perrins. 1998. The birds of the western Palearctic-concise edition. Vol. 1. Oxford Univ. Press, Oxford.

SOKAL, R. R., AND F. J. RoHLF. 1995. Biometry. 3rd ed. W. H. Freeman, NY. 
SOUTHERN, W. E. 1987. Gull research in the 1980s: symposium overview. Stud. Avian Biol. 10:1-7.

Summers, R. W. 1986. Breeding production of Darkbellied Brent Geese (Brant bernicla bernicla) in relation to lemming cycles. Bird Study 33:105108.

Summers, R. W., AND L. G. UnderhiLl. 1987. Factors related to breeding production of Brent Geese (Brant b. bernicla) and waders (Charadrii) on the Taimyr Peninsula. Bird Study 34:161-171.

Summers, R. W., L. G. Underhill, and E. E. SyrOECHKOVSKI. 1998. The breeding productivity of Dark-bellied Brent Geese and Curlew Sandpipers in relation to changes in the numbers of Arctic foxes and lemmings on the Taimyr Peninsula, Siberia. Ecography 21:573-580.

SutTon, G. M. 1932. The exploration of Southampton
Island, Hudson Bay. Memoirs of the Carnegie Museum 12:3-268.

UNDERHILL, L. G. 1987. Changes in the age structure of Curlew Sandpiper populations at Langebaan Lagoon, South Africa, in relation to lemming cycles in Siberia. Trans. Roy. Soc. South Africa 46 209-214.

Underhill, L. G., M. WALtNer, AND R. W. SUMmers. 1989. Three-year cycles in breeding productivity of knots (Calidris canutus) in southern Africa suggest Taimyr Peninsula provenance. Bird Study 36: 83-87.

ZOUTENDYK, P. 1965. The occurrence of Xema sabini off the coast of southern Africa. Ostrich 31:1516.

ZouTENDYK, P. 1968. The occurrence of Sabine's Gull (Xema sabini) off the Cape peninsula. Ostrich 39: 9-11. 